\title{
Scientific Assessments of Bystrinski Evens Socio-cultural Development in 1990-2000s
}

\author{
Alina Igorevna Kirillova ${ }^{1}$ \\ ${ }^{1}$ Vitus Bering Kamchatka State University, Pertopavlovsk-Kamchatskii, Russian Federation \\ Correspondence: Alina Igorevna Kirillova, Vitus Bering Kamchatka State University, Pogranichnaya Street, 4, \\ Pertopavlovsk-Kamchatskii, 683032, Russian Federation. E-mail: astra1155@yandex.ru
}

Received: November 17, 2014

Accepted: November 27, 2014 Online Published: February 25, 2015

doi:10.5539/ass.v11n6p105

URL: http://dx.doi.org/10.5539/ass.v11n6p105

\begin{abstract}
The article analyzes different trends of Far Eastern national minorities socio-cultural development and the process' assessments by Russian scientists. Also modern historical exploration methods used in Russia and foreign countries are described. Author uses monographs on methodological approaches and ethnology, field materials to reveal convergence and divergence trends of ethnical societies' development on the sample of traditional Bystrinski Even culture development in 1990-2000s. Special attention is given to the studies and methods of investigation of modern socio-cultural development in national districts.
\end{abstract}

Keywords: Bystrinskiy district, Bystrinski Even, traditional culture transformation, transformation methodology, Kamchatka

\section{Introduction}

Modern Russian ethnologists and culturologists suppose the period of 1990-2000s to be ambiguous for socio-cultural development of Far Eastern ethnoses. There are two obvious trends influencing ethnical societies: globalization and revitalization. These processes are often opposed. Scientists commonly study revitalization process. Complex studies of both processes simultaneously require special methodological approaches and methods implementation.

Main manifestations of globalization process are: 1) the decrease of native language using and its ousting by Russian; 2) free information access and growth of information value in everyday life due to introduction of new technologies in everyday life such as Internet, social networks, cellular phones, etc.; 3) appearing of new crafts more typical for other tribes; 4) the change of professional preferences. The characteristic features of revitalization can be called 1) appearing and development of mass media in native languages (radio, TV-programmes, newspapers); 2) emergening of communities as keepers of traditions; 3) revival of traditional crafts and occupations (for example, reindeer-breeding, dog-breeding, hunting, etc.). It's important to note that nowadays every manifestation can be found in every ethnos.

Evens appeared in Kamchatka in 1830-1840s. Historians and ethnologists differ one ethnical Even group-Bystrinski Evens (Gurvich, 1960, pp. 63-91) because of their compact living area (the territory of Bystrinskiy district), their Even language dialect and long reserved mode of life (they preferred ethnical endogamy). So up to the Soviet transformations and even then they preserved cultural peculiarities that distinguished them from other Evens' ethnical groups (Gurvich, 1960, pp. 63-91). Studies of Bystrinski Evens as a special local group of Evens ethnos has recently been started in early 2000 s by Kamchatka's explorers. There are few complex works devoted to this local group.

\section{Methodological Approaches and Methods of Studies Globalization and Revitalization Processes}

Transformation methodological approach helps to explain traditional culture development contradictions. According to this theory transformation process has several directions: convergence and divergence. (Poberezhnikov, 2006, p. 231). One of them is increasing convergence that becomes apparent in globalization process, especially in modern social infrastructure development, technological process and equalizing typical mode of life (Ponomarev, Remizov, Karev, \& Bakulev, 2009). Also in national villages cultural transformation process follows in divergence line. Its manifestations can be found in ritual revitalization, native language studies and ethnical community development (Kirillova, 2011). 
Transformation methodological approach and its basic methods (historical-genetic, comparative, observation, case-study etc.) provide complex studies of convergence and divergence cultural processes, transformation of traditional cultures of Russian Far Eastern national minorities. Its wide usage in modern ethnology, anthropology to study the characteristic features of national minorities' socio-cultural development in 1990-2000s is obvious and well-founded. It helps to reveal the complex problems of Bystrinski Evens socio-cultural development and point out the problems to be solved.

Regionalization process in historical science is also obvious and logical because of local scientific schools development. Various ways of regions' development in Russia in 1990-2000s proved the necessity of the special scientific concept of convergence and divergence. It could be used when studying regions and local societies (Treivish, 2001). Case-study method is efficient in local historical processes investigation, because it provides the best cover of the problems and also specifies characteristic features of the investigated territories and ethnical groups (Amenta, 2009; Johansson, 2003; Tai, 2011). For example, Bystrinskiy district of Kamchatka is a reserved territory. Living there Evens managed to preserve their traditional culture. At the same time there lived Koryaks who were friendly to Evens, so Evens borrowed some features of culture from the Koryaks, for example wide use of dog-sleds (traditionally Evens used reindeers for transportation, domesticated dogs were used for hunting) and armories. Evens also borrowed from Itelmens horse-riding. Being a closed territory hidden in the mountains Bystrinskiy district facilitated reserved mode of life and ethnical endogamy among the Evens in the XIX-th century. That's why in the beginning of the XX-th century Bystrinski Evens became a special local group of Even ethnos. In 1990-early 2000s social mobility was low, so the way of life of Bystrinski Evens also had peculiar features different from way of living in Milkovskiy district (where Itelmens live) or Tigilskiy district (where Koryaks live). The characteristic features were conditioned by the nature and cultural traditions (the district is rich in fish and forests, Evens used to fish and live in small family groups). Case-study method allows to take these factors into account.

Nowadays the oral history method is also widely used in Russian History and Ethnology. Memoirs collection is very difficult process, and interpretation of them could be rather subjective, but memoirs of eye-witnesses are important. They could become a means of historical period's atmosphere studies facilitators (Memoirs of Banakanova P. M., Materials of the Cherkanovs, Krechetov V., 2007), likewise photo materials (Radio Broadcasting Story). So we can see that modern historians have different methodologies, methods, ways of collection information and historical sources.

In Russian historical and ethnological sciences oral history method and field observations, even included observation with living a whole economical cycle among the natives, require documentary proof. One of the obvious trends of modern oral history studies and ethnical societies' memoirs trends is negative appreciation of Soviet period and Soviet heritage. It occurred because of too fast transformation processes and strict national and social policy of the Soviet state powers. One more reason of negative Soviet heritage's appreciation was the quick decreasing life-level in 1990s because of reducing donation into economy of national districts of Russian North and Far East. Even Soviet economy supposed these districts' economy to be donated lots of money. Due to objective reasons (limited market, peculiarities of the production, low consuming of ready-made product and genetic problems of reindeer population) reindeer-breading is not profitable trade. It requires sufficient donations even on the modern stage of economy's development. In 1990s when donations stopped, reindeer-breading collective farms were ruined. Unemployment became the real problem of the national societies of Russian North and Far East. The Soviet state was blamed in all the problems, even the problems emerged in early 1990s in the post-soviet period. This trend should be taken into account when explorers analyze memoirs of eye-witnesses.

Transformation methodological approach and case-study method allow to study processes of socio-cultural development of Bystrinski Evens rater objectively. That's why they were chosen by the author. Memoirs of the natives, local press and field observations became the sources of investigation.

\section{Globalization Process and Its Manifestations}

Globalization process causes different estimations between Russian ethnologists (Tishkov, 2003). Some of them (classical Soviet ethnology) suppose globalization to be the disaster for traditional cultures and ethnical societies, especially for national languages and dialects. In fact there's a problem of national language preserving (Complex development of Northern national minorities under conditions of science-technical progress up to 2005. Concept, 1989). Bilingual persons became typical in modern ethnical societies. Native language usage is limited, it's widely in traditional crafts, traditional rituals and dances (mostly oriented on tourism business) and ethnical setting apart. National and political elites use the native languages as the way of ethnical identity 
preserving. It also helps the elites in substantiation of ethnical privileges (fishing and hunting licenses for example).

Another problem caused by globalization is decrease of traditional occupations and youth interest in them (Figure 1). According to the survey (its results are displayed in the Figure 1) young people prefer the job in social sphere. Also they say that reindeer-breeding and traditional hunting are the less desired jobs that could be taken in the terminal case. Many youngsters prefer to live in towns of Kamchatka (Petropavlovsk-Kamchatskii, Yelizovo), telling that jobs and salary in the native villages aren't suitable for them. Also it's worth saying that social infrastructure and industry aren't highly developed in the native villages. The number of vacancies is limited and it's difficult to find job there. Living in the towns they are limited in contacts with traditional culture and native language. That's why they feel more effects of globalization process.

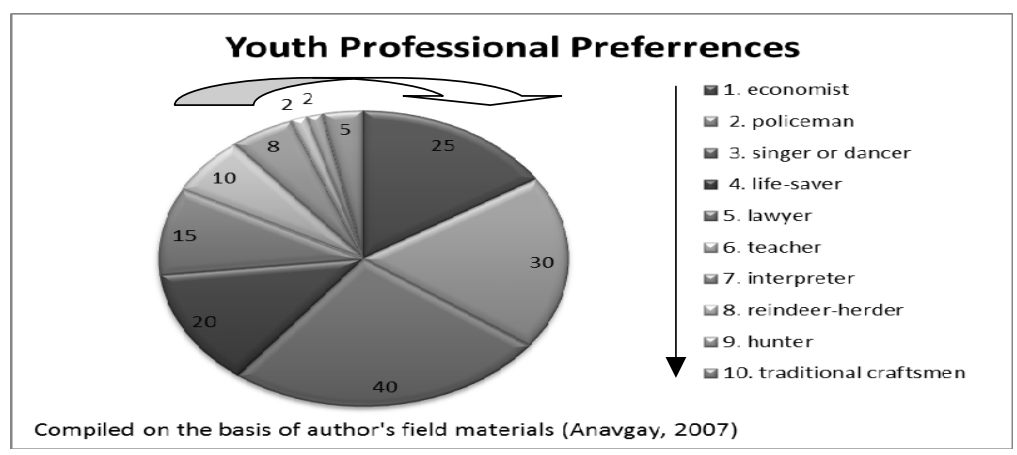

Figure 1. Even youth professinal preferrences (Anavgay, Bystrinskiy district), compiled on the basis of youth survey in Anavgay in 2007. Youngsters were asked about 3-4 preferrable jobs

Youth also is less interested in national language learning and using it in everyday life. Appearing Internet and social networks led to the change of leisure time organization as well. Young people have accounts in one or more social networks, share photos there. Usually they spend 2 or more hours checking their accounts and writing comments. They also play computer games and on-line computer games. Also modern youth spend some time with their gadgets using mobile and computer adds to edit photos, create demotivates, etc. Important role in this process played so-called mobile revolution, now a smartphone is the real must-have for the youngsters older than 7 years. In 1980s and early 1990s they spent this time on traditional crafts studying or communication with elder people or playing traditional games.

Globalization also influences ethnological and local history studies, because the concept of traditional ethnographical field. For example, according to some scientists' opinion nowadays ethnographic field can be called the ethnic diasporas which keep traditional culture, preserve native language, etc. (Tishkov, 2003). Traditional community aimed at political rights and economical benefits protection can also be called some kind of social institution. It also helps to preserve traditional culture, but it's also the way of collaboration with the officials and Russian state. According to transformation methodological globalization process can be defined as convergence process. The Bystrinski Evens mode of life becomes close to the way the most Russians live.

In the villages of Esso and Anavgay convergence process can be seen in tourism development in Bystriskiy district, tourism infrastructure development and diversification of district's economy (reindeer-breeding, ecological and recreational tourism, mining) (Yarotskiy, 2003). It's also noticeable that asphalt roads construction has been recently started in the district. These roads will be the first asphalt ways in Bystrinskiy district from the moment of its emergening in 1926 (Asphalted Roads of Esso and Anavgay, 2014). New roads will increase the integration of district's economy in Kamchatka's regional economical life and improve population life quality as well. Nowadays mode of life in ethnical villages is alike Russian. People use all the modern technologies (Internet, cellular phones, satellite TV, etc.). Mobile connection today covers some zones of clan lands. The natives wear typical European clothes. Russian has become basic communication and nomination language.

That's why convergence process is supposed to be very active and continued. The results of convergence process have become obvious. Youngsters are especially influenced by the globalization process and their mode of life and system of values close to the global ones. 


\section{Revitalization Process and Its Features}

Revitalization of traditional cultures is usually appreciated positively. Scientists suppose the process to provide traditional cultures saving. It should be noted that modern technologies also influence the process. For example today traditional craftsmen use oil instead of seal fat when making traditional black dye (Kirillova, 2012). When they sew traditional clothes they sometimes use cotton or silk thread instead of reindeer sinew (Kirillova, 2012). It happens because of high cost of traditional materials. Nowadays reindeer livestock has rather decreased (Reindeer-breeding requires support, 2008). Herds are pastured rather far from settlements. So in the period of slaughter it's difficult to collect fells and sinews. As to marine animals and fish, modern fishing limits obstacle the process of collecting traditional ingredients.

Native language preserving faces some difficulties as well. For instance, one of them is limited spheres of native language usage. The official language of municipal paper work is Russian. Radio and TV-channels use Russian as well. Programmes on the native languages take less than $5 \%$ of broadcasting time (1 news-block a day, except Saturdays and Sundays). As to Even language, it's not used in the local news programmes. Broadcasters speak Itelmen and Koryak languages. Young people of Bystrinskiy district can speak Even at the lessons of native language and during traditional dances and ceremonies. In everyday life youngsters more often use Russian.

Communities at first were created to provide surviving and represent interests of the natives, especially in cases of fishery and clan lands owning. But Even communities also face some problems in their functioning. Forest Codex of Russian Federation has some gaps that don't allow to legitimize clan lands owning and grant their special status. Another difficulty is the necessity to have constant registration in the settlement. Communities are registered in the villages of Esso and Anavgay, but their real location is far from the villages. That's why agreement for some actions (extra-quotas of fish and animals, using lands for other purposes, building) can be reached long time after or the agreement receiving can be neglected.

These facts prove that revitalization of traditional culture faces many problems in its practical realization. The facts that federal laws and norms influence Even people in their clan lands so-called territories of traditional nature management, introduction of new technologies and materials in traditional crafts, limitation of native language using allow to conclude that even there the native feel globalization process impact. That's why it's difficult to oppose globalization and traditional culture revitalization processes. Revitalization process can be defined as divergence transformation process. It provides the preserve of traditional culture's features that differ Bystrinski Evens from the other ethnoses and ethnical groups of Kamchatka.

Divergence process can be seen in traditional ethnical villages appearing, for example Chauchiv (Koryak village in Esso), Menedek (Even village in Anavgay). Being aimed at ethno tourism development they also provide traditional culture preserving. Also ethnical villages are the base for new and traditional holidays: Even and Koryak New Year (June, 21-22), The First Fish Day, Aborigine's Day, Reindeer-Breeder's Day, Nurgenek and others. In the programme of holidays traditional dances, folk songs (guttural singing especially) and games (jumps on bear's fell, running, catching reindeers, etc.) are always included (Personal Archive of Banakanova L.E.).

Even newspaper "Aydit" that is published in Even language also helps to preserve traditional culture. The newspaper publishes news of Bystrinskiy district, folk fairytales and songs. It also collects memoirs of the natives. Memoirs cover different events, histories of local enterprises and institutions. Aydit is the enclosure to district's newspaper "New Life" (Novaya Zhizn in Russian). The official paper is published in Russian, but also collects memoirs and folk songs.

Divergence trend is also seen in the fact of "fishery villages" (rybalka in Russian) existence. Modern ethnography calls family settlement beyond official village "a fishery village". These settlements are not official and very small (usually there lives 1 family or 3-10 people). Their inhabitants fish and process fish (smoke fish or prepare so-called yukola-traditional Koryak rotten fish), some of them plant potatoes and vegetables (Slugin, 1994, Slugin, 1998). All the products are eaten by the family. As transportation they use horses in summer and dog sledges or snowmobiles in winter. There's no electricity or running water in "fishery villages". That's why the mode of life of such families is quite close to the traditional one.

Due to these trends development divergence cultural process continues. Bystrinski Evens don't loose their ethnical identity and preserve some aspects of traditional culture. Transformation processes of their society are going on, that's preservation of ethnical identity and traditional culture is very important. 


\section{Conclusion}

Transformation methodological approach is one that is widely used in Russia and abroad. It allows to study regional history and history of local societies. Combined with the case-study method it provides objective cover of Far Eastern and Northern Russian national minorities' societies development on the different stages of historical process. It's necessary to note than 19990-2000s is the contradictory period for ethnical societies in Russian North and Far East, because of problems of post-soviet economical and socio-cultural development and re-estimation of Soviet heritage as well. One of the most popular trends is negative estimation of Soviet period; it's supposed to be the time of ethnical identity and traditional culture decline and neglect. Historians note too high speed of transformation process. At the same time the collapse of donations into traditional trades (reindeer-breading, hunting, fishing) led to their decay and economical crisis in the national districts. It conditioned the search of alternative ways of development and revitalization of traditional mode of living, on the family lands in so-called fishery villages.

Russian socio-cultural policy for national minorities and local ethnical societies is also contradictory. On the one hand, federalization and creation of universal nation's culture, uniting all the peoples living in the country into one community "Russian citizens", is going on. On the other hand, preserving traditional culture, mode of life and trades, languages and religious ideas as well is performed. There are special national programmes of Russian Federation's government aimed at ethnical peculiarity preserving. In fact they reflect two ways of transformation of ethnical societies-globalization (convergence) and revitalization (divergence). These two processes nowadays are going simultaneously and influence the ethnical societies' development every day.

In the Bystrinskiy district convergence process is very active and can be seen among the youth objectively, especially in professional preferences and native language using (it's not used nearly at all and spheres of its usage are limited: tourist attraction, traditional holidays, elder people communication, lessons of native language). The divergence process is also keeping on. Some Evens and even young people prefer to live in the fishery villages. They net fish, process it and use for living. Their mode of life is quite close to the traditional one At the same time the volume of fish to be caught is regulated by Russian Federation law, the territories are not protected by the officials. All the Evens have official registration in Esso and Anavgay villages and can get welfare payments (unemployment benefit, children's allowance, different kinds of pensions, etc.). It's worth saying that sometimes Evens from fishery villages visit Esso and Anavgay, receive their public payments and buy necessary goods on them. That's why we can conclude that even people living in the fishery villages are incorporated in modern society and use the achievements of capitalist economy. They also register their marriages according to Federal laws. One of the traditional Even trades fur-animals hunting is now forbidden because of Bystrinskiy natural park foundation and saving the population of fur-animals. People caught on poaching could be arrested and imprisoned.

Ethnologists and historians suppose that revitalization of traditional culture in the full volume nowadays is impossible because of changed mentality and globalization. At the same time these attempts are estimated positively. Globalization process is considered to be inevitable and irreversible. The influence of these two processes on the ways of ethnical societies' development is investigated. In 1990-2000s in Russian Federation this contradiction appeared and became obvious. The correlation of convergence and divergence processes is interesting to be investigated in the future, because now the globalization process dominates. But the revitalization process is not decreasing, ethno-tourism development requires the explorations and preserve of traditional culture.

The fact that Bystrinski Evens preserved elements of their traditional ethnical culture and ethnical identity prove that globalization (convergence) process couldn't grade their socio-cultural peculiarities. Their readiness to study and preserve some traditions shows that divergence process is going on. Exploration of transformation processes in modern ethnical societies can be continued and can provide a lot of interesting information. The case of Bystrinski Evens is also interesting because they are not indigenous people of Kamchatka, but have incorporated into its ethnical community rapidly. Nowadays some ethnologists consider them to be Kamchatka's natives. That's why complex and detailed case-study of Bystrinski Evens is required and actual.

\section{References}

Amenta, E. (2009). Making the Most of an Historical Case Study: Configuration, Sequence, Casing, and the US Old-age Pension Movement. In The SAGE Handbook of Case-Based Methods (pp. 351-366). http://dx.doi. org/10.4135/9781446249413.n21

Asphalted Roads of Esso and Anavgay. Retrieved July 8, 2014, from http://kamchat.info/novosti/dorogi_esso_i_ anavgaya_zaasfal_tiruyut_kamchatka/ 
Complex development of Northern national minorities under conditions of science-technical progress up to 2005. Concept. (1989). Moscow.

Gurvich, I. S. (1960). Evens of Kamchatskaya Oblast. In Modern Economy, Culture and Way of Life of Nothern Ethnoses. Investigations of N.N. Miklukho-Maklai Ethnographical Institute, LVI, 63-91. Moscow: Science.

Johansson, R. (2003). Case Study Methodology. Methodologies in Housing Research (pp. 1-14). Royal Institute of Technology in cooperation with the International Association of People-Environment Studies, Stockholm, Sweden.

Kirillova, A. I. (2011). The role of Communes in Preserving and Popularization of Northern Ethnoses' Traditional Culture on the sample of Bystrinskiy District. Problems of Revitalization, Preserving and Popularization of Northern, Siberian and Far Eastern National Minorities Traditional Culture (pp. 212-216). Petropavlovsk-Kamchatski.

Kirillova, A. I. (2012). Diary of ethnographical field observations (p. 14). Anavgay.

Krechetov, V. (2007). Memoirs. In V. I. Borisov (Ed.), Memoirs of Kamchatka's Residents. XX-th century (pp. 52-56). Petropavlovsk-Kamchatski.

Materials of the Cherkanovs. (2015, March). Materials of Ethnographical Expadition of KamSU to Anavgay.

Memoirs of Banakanova P.M. Materials of Ethnographical Expadition of KamSU to Anavgay. (2005, March).

Personal Archive of Banakanova L.E. Materials of Ethnographic expedition to Anavgay. (2005, March 13-21).

Poberezhnikov, I. V. (2006). Transfer from Traditional to Industrial Society: Theoretical and methodological problems. Moscow: Rosspen.

Ponomarev, I., Remizov, M., Karev, R., \& Bakulev, K. (2009). Modernization of Russia as the way of New State Construction. Expert Report. Retrieved March 14, 2011, from http://www.apn.ru/publications/ article22100.htm

Radio Broadcasting Story. Materials of Esso Municipal Archive. Photo materials.

Reindeer-breeding requires support. (2008). Kamchatka's Aborigine, 28(5).

Slugin, A. Y. (1994). In the Ethnographical Expedition. Novaya Zhizn, 82(2).

Slugin, A. Y. (1998). The Call of Ancestors. Kamchatka's Aborigine, (4).

Tai, M. (2011). The Nexus of Modernization and Social Capital: A Comparative Exploration of Two Kenyan Villages. Middletown, Connecticut.

Tishkov, V. A. (2003). Requiem for Ethnos. Moscow: Science.

Treivish, A. I. (2001). Regionalization in Russia's Development: Geographical processes and problems. Moscow.

Yarotskiy, G. P. (2003). General Scheme of Nature Management in Kamchatka Peninsula and Adjacent Waters. Map. Petropavlovsk-Kamchatski.

\section{Copyrights}

Copyright for this article is retained by the author(s), with first publication rights granted to the journal.

This is an open-access article distributed under the terms and conditions of the Creative Commons Attribution license (http://creativecommons.org/licenses/by/3.0/). 